Proceedings of the Annual Conference of the Agricultural Extension Society of Nigeria

Number: Twenty-Fifth Annual Conference

Theme: Enhancing the Role of Public and Private Extension in Soil Conservation and

Agricultural Productivity

Date: 28-29, July 2020

Venue: Usmanu Danfodiyo University, Sokoto, Nigeria

ISSN: 1595 - 1421.http://aesonnigeria.org/ConfProc . Email: editorinchief@aesonnigeria.org

\title{
Level of Savings among Maize Farmers in Doma Local Government Area of Nasarawa State, Nigeria
}

https://dx.doi.org/10.4314/jae.v25i1.3S

\author{
Umar, Haruna S. \\ Department of Agricultural Economics and Extension, Nasarawa State University, Keffi, \\ Nigeria \\ Email: umarhsuleiman@yahoo.com, Mobile Phone: 08142473022

\section{Peter, Emmanuel} \\ Department of Agricultural Economics and Extension, Nasarawa State University, Keffi, \\ Nigeria \\ Email: emmapeter@yahoo.com, Mobile Phone: 08023645575
}

\begin{abstract}
The study examined level of savings among maize farmers in Doma Local Government Area of Nasarawa State, Nigeria. Multistage sampling procedure was used to select 80 respondents in the study area. Primary data were collected using well-structured questionnaire. Data were analyzed using descriptive statistics and Multiple Linear Regression. The results show that half of the respondents $(50.0 \%)$ were within the age bracket of 21 - 40 years with a mean age of 42 years. Majority (83.8\%) of the respondents were married. About $26.2 \%$ of the respondents had between 11 and 15 years of farming experience. More than half (56.2\%) of the respondents belong to one cooperative association or another. Most of the respondents (81.2\%) had access to extension contact with $46.3 \%$ of the respondents operating savings accounts with commercial banks. Household size $\left(0.819^{* *}\right)$, farming experience $\left(-0.589^{* *}\right)$, membership of association $\left(-5.635^{\star *}\right)$ and revenue from maize farming $\left(0.00028^{* *}\right)$ were significant at $5 \%$ and constitute major determinants of savings in the study area. It is recommended that efforts should be made to increase earnings from maize farming through improved productivity by appropriate extension service. Also, savings with the financial institutions by the maize farmers should be encouraged through whittling down of administrative bottlenecks and, through extension of collateral-free credit facilities to them.
\end{abstract}

Keywords: Savings, maize farmers, commercial banks

\section{Introduction}

Nigeria is primarily regarded as an agrarian nation producing virtually all the basic food consumed by its populace, though self-sufficiency and food security still remain major challenges. Maize is one of the most important staple foods in Nigeria and accounts for about 40 percent of daily calories and has per capital consumption of 98 kilograms (Umar et al; 2017). It consumed as pap, popcorn, thick porridge and boiled grains in many parts of the country. Maize is industrially important for the production 


\section{Proceedings of the Annual Conference of the Agricultural Extension Society of Nigeria}

Number: Twenty-Fifth Annual Conference

Theme: Enhancing the Role of Public and Private Extension in Soil Conservation and Agricultural Productivity

Date: 28-29, July 2020

Venue: Usmanu Danfodiyo University, Sokoto, Nigeria

ISSN: 1595 - 1421.http://aesonnigeria.org/ConfProc . Email: editorinchief@aesonnigeria.org

of starch, alcohol, and animal feeds. Maize, all things been equal, thrives best in a warm tropical climate and is grown in all parts of Nigeria, but performs better in a well-drained fertile loamy soil (IITA, 2012). Maize production in Nigeria is practiced at subsistence level and is characterized by numerous smallholder farmers operating several scattered small and fragmented plots of land using traditional methods. Most of these farmers operating at subsistence level suffer economic deprivation resulting from poor and low income. However, the quest for enhancement of farmers' fortune and poverty eradication will require greater investment in agriculture. On the other hand greater investment in agriculture requires personal savings from owner's equity and accessibility to credit capital. Savings is basically considered in economics as disposable income less personal consumption expenditure. It could also be regarded as income that is not immediately expended on buying goods and services. Income in this concept denotes the cumulative earnings from all sources for the year (Nwibo, 2013). Savings simply means putting aside certain portion of one earned value for future use or investment. Jhingan (2004), simply define savings as the difference between disposable income and consumption that is, $S=Y-C$, where $S$ is savings, $\mathrm{Y}$ is income and $\mathrm{C}$ consumption. Savings can also be referred to as that portion of disposable income that is not devoted to current consumption Savings behaviour is very imperative for supporting and developing rural enterprises, improving wellbeing, insuring against uncertainties, and providing a buffer to help people stand in times of crisis (Maltin and Hulme, 2012). According to Olawepo (2015), households' savings play a vital role in the economic development of both developed and developing societies, considering their significant influence on the circular flow of income in the economy. Nigerian agriculture is still at a subsistence level, as farm activities are mainly in the hands of smallholder farmers which serves as their major means of livelihood (FGN, 2008). However, their ability to sustain and improve their farm output has been constrained by lack of finance and this could be attributed partly to poor savings behavior particularly among rural farmers. The common saving type among subsistence farmers is the informal financial sectors like cooperative society, thrift society etc. Saportel (2012), observed that farmers make use of informal financial sectors to mobilize savings to improve on farming and develop their rural communities. Zhibin (2015), rural farmers make use of informal financial institutions because they give them easy access to loans which ordinarily not available from formal financial institutions due to lack of collateral.

These informal sectors nonetheless have their own peculiar challenges such as inadequate capital base for effective operation, poor record keeping, low disbursement, crude accounting system and gross mismanagement etc. However, farmers still prefer them to banks as the latter have become increasingly difficult to access (Chandra and Long, 2013). Ogwanighie (2017) observed that policy makers and other stakeholders have not really drawn up a robust rural savings scheme that will encourage farmers to invest their capital productively. Inadequate savings and subsequent poor investment by the small scale farmers are considered as major problems confronting the development of agricultural sector in Nigeria. 


\section{Proceedings of the Annual Conference of the Agricultural Extension Society of Nigeria}

Number: Twenty-Fifth Annual Conference

Theme: Enhancing the Role of Public and Private Extension in Soil Conservation and Agricultural Productivity

Date: 28-29, July 2020

Venue: Usmanu Danfodiyo University, Sokoto, Nigeria

ISSN: 1595 - 1421.http://aesonnigeria.org/ConfProc . Email: editorinchief@aesonnigeria.org

Hence, the general objective of the study was to examine the socio-economic factors affecting the savings behavior among maize farmers in Doma Local Area of Nasarawa State. Specifically, the study was intended to: (i) describe socioeconomic characteristics of maize farmers in the study area; (ii) assess the media of savings among maize farmers in the area; (iii) describe level of savings among target farmers in the study area; and, (iv) examine the socioeconomic factors influencing level of savings among maize farmers in the study area.

\section{Methodology}

The research was carried out in Doma Local Government Area in the southern zone of Nasarawa Agricultural Development Programme (NADP) of Nasarawa State, Nigeria. The area is located within latitude $0.9^{0} 33^{\prime} \mathrm{N}$ and longitude $0.9^{0} 32^{\prime} \mathrm{E}$. It has an area of $2,714 \mathrm{~km}^{2}$ and a population of 139,607 people (NPC, 2006). The area is known for the production of crops such as maize, sesame, yams, melon, rice, groundnut, millet and sorghum.

A multi-stage random sampling procedure was used to sample 80 respondents in the study area. The first stage was the purposive selection of two out of the ten wards in Doma Local Government Area areas in the zone. The selection of two wards was done given the preponderance of the maize farming in the area. Secondly, four villages were purposively selected from each of the two wards in the study area based on the concentration of maize farmers who are predominantly large scale maize-farmers in the area. In the last stage, lists of maize farmers from each of the eight villages were collected from the village head and extension officers. This list was considered and used as sample frame from which fifteen percent of maize farmers were selected proportionately from each village through simple random technique. This gives a total of eighty maize famers as sample size for the study.

Primary data were generated through the use of structured questionnaire that were administered to maize farmers. The data collected covered information on the demographic characteristics of maize farmers, the media and level of savings by the maize farmers in the study area.

The data collected were analyzed using descriptive statistics (such as frequency, percentage, mean and standard deviation) and ordinary least square (OLS) regressions method. Socio-economic characteristics of the maize farmers and their choice of media for saving were summarized using simple descriptive statistics namely frequency, percentage, mean and standard deviation. The level of saving of the household was analyzed using the equation below:

Saving Level $=\frac{\text { Amount Saved }}{\text { Total Income }} \times 100$

While ordinary least square (OLS) regressions method was used to analyze the influence of Socio-economic factors on respondents' level of savings. 
Proceedings of the Annual Conference of the Agricultural Extension Society of Nigeria

Number: Twenty-Fifth Annual Conference

Theme: Enhancing the Role of Public and Private Extension in Soil Conservation and Agricultural Productivity

Date: 28-29, July 2020

Venue: Usmanu Danfodiyo University, Sokoto, Nigeria

ISSN: 1595 - 1421.http://aesonnigeria.org/ConfProc . Email: editorinchief@aesonnigeria.org

The implicit OLS model for this study was specified as:

$Y=f\left(X_{1}, X_{2}, X_{3} \ldots, X_{n}\right)$

This model is expressed explicitly as:

$Y=\beta_{0}+\beta_{1} X_{1}+\beta_{2} X_{2}+\beta_{3} X_{3}+\beta_{4} X_{4}+\beta_{5} X_{5}+\beta_{6} X_{6}+\beta_{7} X_{7}+\mu$

Where;

$\mathrm{Y}=$ saving level $(\%)$

$\mathrm{X}_{1}=$ Age of the respondents (years)

$\mathrm{X}_{2}=$ Household size (number)

$X_{3}=$ Education level (number of years spent in school)

$\mathrm{X}_{4}=$ Farm size (hectare)

$\mathrm{X}_{5}=$ Farming experience (years)

$\mathrm{X}_{6}=$ Membership of farmers association $(\mathrm{Yes}=1, \mathrm{No}=0)$

$\mathrm{X}_{7}=$ Revenue from maize farming $(\mathrm{A})$

$\mu=$ Error term

$\beta_{0}=$ Intercept

$\beta_{1}-\beta_{7}=$ Regression parameters to be estimated.Results and Discussion

\section{Socioeconomic Characteristics of Respondents}

The results in Table 1 reveals that half of the respondents $(50.0 \%)$ were within the age range of $21-40$ years, $37.5 \%$ were within the age range of $41-60$ years. The mean age was 42 years. This indicates that small holder farmers in the study were mostly in their productive age. It was also observed that majority (83.8\%) of the maize farmers were married. This therefore implies that the married classes were more involved in maize farming because of the need to supplement the family's means of livelihood. Furthermore, the Table shows that majority (57.5\%) of the respondents had one form of formal education or the other, while $42.5 \%$ of the respondents had not attended any form of formal education. This implies that the respondents were to a large extent literate. Possession of literacy (ability to read and write) would enable the farmers to better utilize effectively and efficiently available production resources in the area. All things being equal, higher education is expected to enhance the saving and investment of the maize farmers, hence increased farm income (Ezeh, 2010).

The household size data revealed that $43.8 \%$ had a household size of between of $6-10$ persons. The mean household size was 11 persons approximately. The relevance of family 


\author{
Proceedings of the Annual Conference of the Agricultural Extension Society of \\ Nigeria \\ Number: Twenty-Fifth Annual Conference \\ Theme: Enhancing the Role of Public and Private Extension in Soil Conservation and \\ Agricultural Productivity \\ Date: 28-29, July 2020 \\ Venue: Usmanu Danfodiyo University, Sokoto, Nigeria \\ ISSN: 1595 - 1421.http://aesonnigeria.org/ConfProc . Email: editorinchief@aesonnigeria.org
}

size however in agriculture cannot be overlooked as it provides more family labour which influences the size of land cultivated and in turns the amount of farm produce harvested (Yusuf, 2016). However, this scenario is also associated with high rate of malnutrition, mortality, illiteracy, unemployment especially in many rural economies, which also affect savings behaviour (Okorji, 2011). The distribution of respondents based on farm size also revealed that majority $55.0 \%$ had farm size of between 1 and 3 hectares. The mean farm size was 4 hectares approximately. This shows that the respondents in the study area were mostly small scale farmers. Onumadu (2010) in his studies stated that most farmers in the rural area generally have small holdings due to tenure systems. The small farm size can reduce the farmers' ability to save because the output from such farm would be small resulting in meager revenue. The bigger the farm size, the higher the propensity to save (Yinusa, 2011).

As regard to farming experience, the result revealed that $26.2 \%$ had farming experience of between 11-15 years. The mean farming experience was approximately 18 years. The ability of the farmers to manage their farm business and make informed decisions on his farm is dependent on his farming experience. According to Mbat (2015), farmers with long experience in farming are likely to make decisions that would increase their output, income, savings as well as their investment.

The result also shows that majority (56.2\%) belonged to one cooperative group or the other, while $43.8 \%$ do not belong to any cooperative association. This implies that most of the respondents may be able to access informal loan through this cooperative. Their ability to access loans can assist in increasing their investments and hence their savings (Okorji, 2011). Odoemenem et al. (2013) in their earlier studies indicated that farmer make use of informal financial sectors to mobilize savings and develop their rural communities because it gives them access to loans that they cannot get from formal financial institutions due to lack of collateral.

Table 1 also shows that majority of the respondents $(81.2 \%)$ had extension contact, while only $18.8 \%$ had no access to extension contact. The primary objective of extension education is the dissemination of agricultural findings that can improve farmers' welfare and increase their income (Osondu and Ibezim, 2013). Maize farmers' access to credit facilities presented in the Table 1 also revealed that majority (82.5\%) had no access to loan from financial institutions, while only $17.5 \%$ was able to access loan from financial institutions. This implies that maize farmers in the study area were unable to access loan which could likely be attributed to lack of collateral security required by these financial institutions. It is generally assumed that if maize farmers could access easy, timely and cheaper credit facilities, it will ultimately increase their investments and savings. 
Proceedings of the Annual Conference of the Agricultural Extension Society of Nigeria

Number: Twenty-Fifth Annual Conference

Theme: Enhancing the Role of Public and Private Extension in Soil Conservation and

Agricultural Productivity

Date: 28-29, July 2020

Venue: Usmanu Danfodiyo University, Sokoto, Nigeria

ISSN: 1595 - 1421.http://aesonnigeria.org/ConfProc . Email: editorinchief@aesonnigeria.org

Table 1: Socioeconomic characteristics of the respondents in the study area

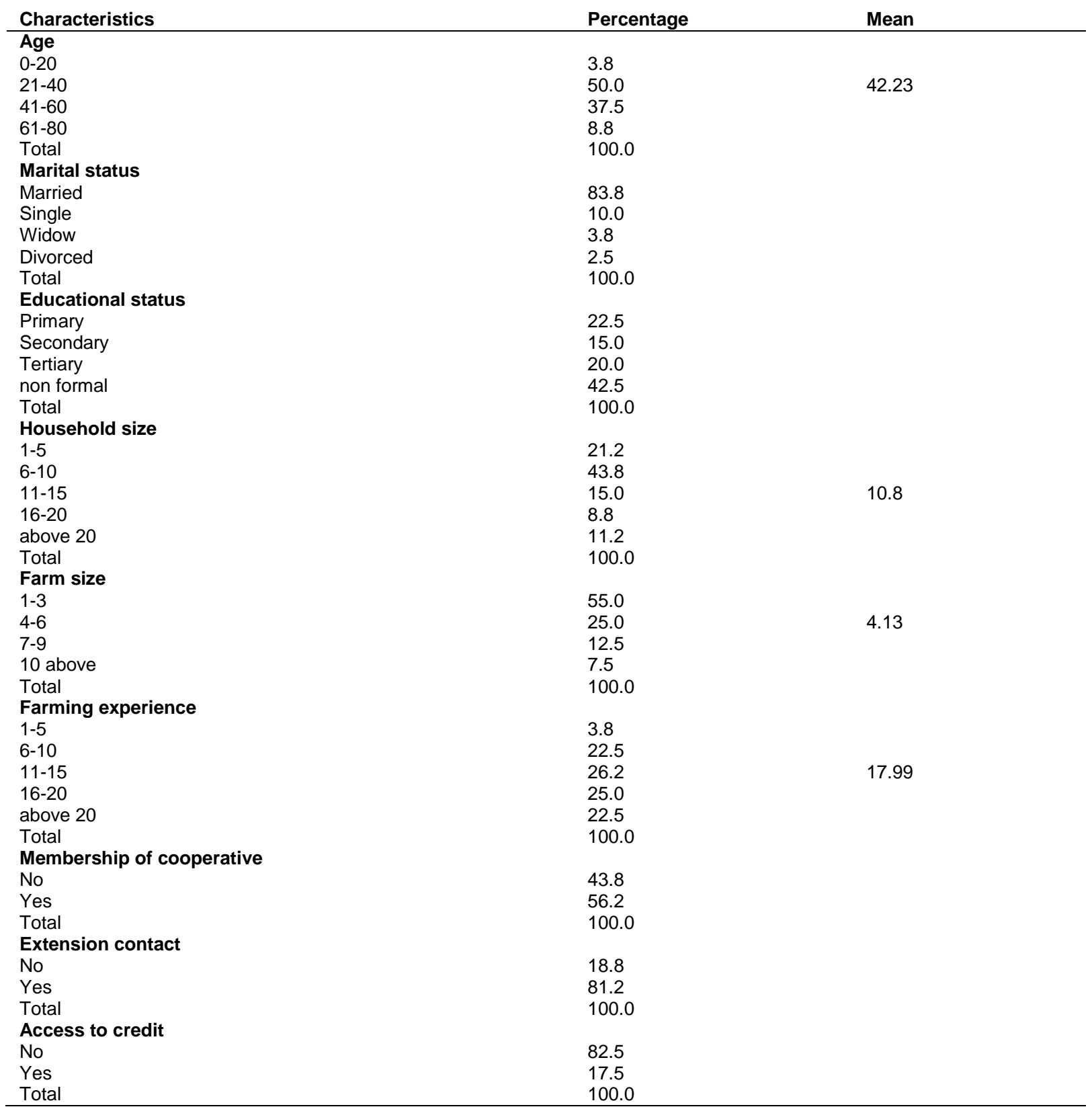

Source: Field survey, 2018

\section{Media for Savings by Respondents}

The analysis of media for saving by maize farmers in the study area presented in Table 2 shows that majority $(46.3 \%)$ of the respondents used commercial banks for their saving, $41.3 \%$ used personal saving, while $10.0 \%$ of the respondents saved their income with cooperative association. Only $7.5 \%$ used friends/relative as their medium of savings. This shows that most of the maize farmers prefer to save their money with commercial banks 
Proceedings of the Annual Conference of the Agricultural Extension Society of Nigeria

Number: Twenty-Fifth Annual Conference

Theme: Enhancing the Role of Public and Private Extension in Soil Conservation and

Agricultural Productivity

Date: 28-29, July 2020

Venue: Usmanu Danfodiyo University, Sokoto, Nigeria

ISSN: 1595 - 1421.http://aesonnigeria.org/ConfProc . Email: editorinchief@aesonnigeria.org

generally considered as more reliable and that farmers can retrieve their savings from them any time. The less preferred means of savings by these farmers is friends/relative perhaps due to propensity of trust betrayal when it concerns money.

Table 2: Media for savings

\begin{tabular}{lc}
\hline Means of savings & Percentage \\
\hline Commercial bank & 46.3 \\
Personal savings & 41.3 \\
Cooperatives & 10.0 \\
Friends/relatives & 7.5 \\
\hline
\end{tabular}

Source: Field survey, 2018

*Multiple responses allowed.

\section{Level of Savings by Respondents}

Table 3 shows the level of saving by the respondents in the study area. The result reveals that $31.3 \%$ of the maize farmers were able to save between $31-40 \%$ of their total farm income, $26.3 \%$ saved between $51-60 \%$ of the total income and $20.0 \%$ saved between 41 $50 \%$ of their total income. The mean savings proportion was approximately $42 \%$. The minimum and maximum saving level was $18 \%$ and $93 \%$ with a standard deviation of 13.6 . These results imply that farmers in the study area were able to save part of their income. This saving ability of the respondents also means that the farmers will be able to increase their investments.

\begin{tabular}{lc}
\multicolumn{2}{l}{ Table 3: Proportion of savings by respondents } \\
\hline Saving level (\%) & Percentage \\
\hline $10-20$ & 1.3 \\
$21-30$ & 12.5 \\
$31-40$ & 31.3 \\
$41-50$ & 20.0 \\
$51-60$ & 26.3 \\
$61-70$ & 7.5 \\
$>70$ & 1.3 \\
Minimum & 17.90 \\
Maximum & 93.30 \\
Mean & 41.52 \\
Standard Deviation & 13.54 \\
\hline
\end{tabular}

Source: Field survey, 2018

\section{Influence of Socioeconomic Characteristics on the Level of Savings}

Table 4 shows the results of regression analysis: out of the seven explanatory variables regressed against level of savings, three were statistically non-significant and these were age, level of education and farm size. On the other hand, four independent variables were statistically significant and they include household size, farming experience, membership of association and farm revenue. The farm revenue was positively and highly significant to maize farmers saving level, indicating $1 \%$ significant $\left({ }^{* * *} \mathrm{P}<0.001\right)$. This is consistent with $a$ priori expectation that as farmers have more farm revenue it is most likely they will save more. While household size was also positively significant to maize farmers saving level, 


\author{
Proceedings of the Annual Conference of the Agricultural Extension Society of \\ Nigeria \\ Number: Twenty-Fifth Annual Conference \\ Theme: Enhancing the Role of Public and Private Extension in Soil Conservation and \\ Agricultural Productivity \\ Date: 28-29, July 2020 \\ Venue: Usmanu Danfodiyo University, Sokoto, Nigeria \\ ISSN: 1595 - 1421.http://aesonnigeria.org/ConfProc . Email: editorinchief@aesonnigeria.org
}

indicating $5 \%$ significant $\left({ }^{* *} \mathrm{P}<0.005\right)$. This is also consistent with a priori expectation that more family labour would increase total farm return that can enhance saving. However, farming experience and membership of association were negatively significant at $5 \%$ $\left({ }^{*} \mathrm{P}<0.005\right)$. This implies that increasing these variables would reduce the farmers' saving level. The coefficient of determination $\left(R^{2}\right)$ is 0.591 , implying that about $60 \%$ of the variation in dependent variables were explained by the independent variables related to the farmers' ability to save.

Table 4: Result of OLS regression of socioeconomic characteristics on the level of savings

\begin{tabular}{lccc}
\hline Variables & Coefficients & Std. Error & t-value \\
\hline Constant & 22.805 & 5.147 & 4.431 \\
Age & -0.049 & 0.174 & $-0.280^{\mathrm{NS}}$ \\
Household size & 0.819 & 0.339 & $2.410^{\star *}$ \\
Educational level & 0.313 & 0.197 & $1.584^{\mathrm{NS}}$ \\
Farm size & -0.950 & 0.650 & $-1.462^{\mathrm{NS}}$ \\
Farming experience & -0.589 & 0.230 & $-2.556^{\star \star *}$ \\
Membership of & & & \\
association & & 2.353 & $-2.395^{\star *}$ \\
$\begin{array}{l}\text { Revenue from maize } \\
\text { farming }\end{array}$ & -5.635 & & \\
\hline${ }^{* \star *} \mathrm{P} \leq 0.01,{ }^{* *} \mathrm{P} \leq 0.05, \mathrm{R}^{2}=0.591$ Source: Field survey, 2018 &
\end{tabular}

\title{
Conclusion and Recommendations
}

The findings of the study revealed that revenue from maize farming and household size positively influenced maize farmers' level of savings in the study area. While farming experience and membership of association negatively influenced maize farmers' level of savings. Majority of the maize farmers (46\%) saved their income or revenue from maize farming with commercial banks. While the mean level of savings was $41 \%$ of total income from maize farming. It is recommended that efforts should be made to increase earnings from maize farming through improved productivity. This can be achieved through extension service targeted at efficient inputs combination. Also, savings with the financial institutions by the maize farmers should be encouraged through whittling down administrative bottlenecks and, through extension of collateral-free credit facility to them.

\section{References}

Chandra, F., and Long, H. (2013), "Determinants of Saving Behavior in Rural and Tribal Households: An Empirical Analysis of Visakhapatnam District", International Journal of Research in Social Sciences, http://www.ijmra.us, Vol. 2, (8).

Ezeh, C.I. (2010). Poverty Profiles and Determinants of Expenditures of Rural Women Households in Abia State, Nigeria". The Nigerian Journal of Development Studies. 6 (1): $187-204$ 
Proceedings of the Annual Conference of the Agricultural Extension Society of Nigeria

Number: Twenty-Fifth Annual Conference

Theme: Enhancing the Role of Public and Private Extension in Soil Conservation and Agricultural Productivity

Date: 28-29, July 2020

Venue: Usmanu Danfodiyo University, Sokoto, Nigeria

ISSN: 1595 - 1421.http://aesonnigeria.org/ConfProc . Email: editorinchief@aesonnigeria.org

Issahaku, H. (2014), "Determinants of Saving and Investment in Deprived District Capitals in Ghana -A Case Study of Nadowliin the Upper West Region of Ghana", Wilolud Journals, Continental J. Social Sciences 4 (1): 1 -12, 2014.

lyoha, M.,Oyefusi, S. A. and Oriakhi, D. E. (2013). An introduction to modern Macroeconomics. Mindex publishing, Benin City, Nigeria.

Jaffer, T. (2014), "Savings Behavior in Gujarat", Margin, Vol. 12, No. 1.

Jhingan, M.L. (2004). Principle of Economics 2nd Edition. Pp. 520-525.

Kendall, J. (2017), "Household Saving Behavior in the Developing Economies: The Indonesian Case", The University of Chicago Press, Vol. 16, No. 3, pp. 385-403.

Khandker, G. (2016), "Determinants of Household Saving: Case Study of Smallholder Farmers, Entrepreneurs and Teachers in Rural Areas Of Kenya", Journal of Development and Agricultural Economics, Vol. 1(7).

Maltin, H., Hulme, D., and Rutherford, S (2012)."International Evidence on the Determinants of Private Saving”, The World Bank Economic Review, Vol. 12, No. 3: 483-501.

Mbat, D.O. (2015) Savings Habit of Rural household in Cross-River state. An Exploratory study" University of Calabar Savings and Development No. 4 Vol. IX.

Nwibo, S.U and Mbam, B.N. (2013). Determinants of Savings and Investment Capacities of Farming Households In Udi Local Government Areas of Enugu State, Nigeria. Research Journal of Finance and Accounting, 4 (15):59-64.

National Population Commission (NPC), (2006) National Population Commission. Population Census Statistics, Abuja, Nigeria.

Odoemenem, I.U. Ezike, K.N.N., Alimba, J.O. (2015), Assessment of Agricultural Credit Availability to Small-scale Farmers in Benue State. Journal of Agricultural Science and Technology, Vol. 15(1\&2) pp. 79-87.

Ogwanighie, A. M. (2017), Savings and Investments Pattern of small scale farmers in some selected villages in Ogbadibo Local. Government Area, Benue State, Nigeria.

Okorji, E.C. (2011). Consequences of Agricultural Productivity of Crops Stereotyping along sexline, Anambra State. M.Sc. Thesis, Department of Agricultural Economics, University of Nigeria, Nssuka, Enugu State, Nigeria

Olawepo, R. A. (2015), Determining Rural Farmers' Income: A Rural Nigeria Experience. Journal of African studies Development Vol. 2(4) pp 99-108.

Onumadu, F.N. (2010). Analysis of factors affecting Cocoyam Production in Umuahia North L.G.A of Abia State, Nigeria. Journal of Agriculture and Social Research (JASR). 9(1): 149-155. 
Proceedings of the Annual Conference of the Agricultural Extension Society of Nigeria

Number: Twenty-Fifth Annual Conference

Theme: Enhancing the Role of Public and Private Extension in Soil Conservation and Agricultural Productivity

Date: 28-29, July 2020

Venue: Usmanu Danfodiyo University, Sokoto, Nigeria

ISSN: 1595 - 1421.http://aesonnigeria.org/ConfProc . Email: editorinchief@aesonnigeria.org

Osondu, C.K. and Ibezim, G.M.C. (2013). Determinants of rural-urban migration and its effect on rural farm labour availability in Umuahia North Local Government Area of Abia State, Nigeria. Research Webpub, 1(3): 29-35.

Saportel, E. (2012), "Analysis of Savings Determinants among Agro-based firm Workers in Nigeria: a Simultaneous Equation Approach", Research on Humanities and Social Sciences,www.iiste.org, Vol.1, No.3.

World Bank. (2018), Africa Can Help to Feed Africa: Removing Barriers to Regional Trade in Food Staples; Africa Food Report No. 66500-AFR.

Yinusa, A.H (2011) "Some Socio-Economic Determinants of Rural Saving Behaviour in Igabi Local Government Area of Kaduna State." Unpublished M.Sc Thesis Submitted to Department of Agricultural Economic Ahmadu Bello University, Zaria.

Yusuf, H.O. (2016). Comparative analysis of gender accessibility to productive resources in Ginger production for poverty alleviation in Kaduna State. Unpublished Ph.D Thesis

Zhibin, F. (2015). Perceived saving motives and hierarchical financial needs. Financial Counseling and Planning, 5(1), 25-44. 